\title{
Go-Food Features and Social Implications in The Community When \#Dirumahaja Programs Are Implemented
}

Edy Prihantoro ${ }^{1}$, Didin Mukodim², Noviawan Rasyid Ohorella ${ }^{3}$, Astiyani Lestari ${ }^{4}$

${ }^{1}$ Master of Communication Science Faculty, Gunadarma University, Indonesia

${ }^{2}$ Gunadarma University, Indonesia

${ }^{3}$ Master of Communication Science Faculty, Gunadarma University, Indonesia

${ }^{4}$ Gunadarma University, Indonesia

\begin{abstract}
Article Info

Volume 7, Issue 6

Page Number: 255-262

Publication Issue :

November-December-2020

\section{Article History}

Accepted : 15 Nov 2020

When the Covid-19 pandemic begins to spread in Indonesian society, the government must limit the space for people to stay indoors. The government has done everything from closing schools and public facilities to implementing Large-Scale Social Restrictions (PSBB) in order to break the chain of spreading the Covid-19 virus. Then the Indonesian people reminded each other to stay indoors. Until the hashtag \#dirumahaja appeared on Twitter social media. Due to the limited space for people to leave the house, especially when buying food, people choose to take advantage of advanced technology by buying food online using the GoFood Feature Gojek application. The purpose of this study was to determine how much the effectiveness of the GoFood features in the Gojek application on the ease with which people order food when \#dirumahaja is implemented. The research method used is descriptive method with a quantitative approach and has a total of 244 respondents. Collecting data using a questionnaire technique or distributing questionnaires. The theory used in this research is the Technology Acceptance Model. The results of this study are that there is an effect of the Go-food feature in the Gojek application on the ease with which people order food when the \#dirumahaja Program is implemented. The ease of features in the Gojek application turns out to make it easier for people who need food through the Gojek application during the Pandemic.
\end{abstract}

Published : 30 Nov 2020
Keywords: GoFood, Gojek Application, Effectiveness,\#dirumahaja, Food.

\section{INTRODUCTION}

\section{A. Background}

The very rapid development of the internet makes almost everyone in the world use the internet. The digital era is an era where everyone can easily get what they want and there are no limits. This was followed by the times that brought people to activities with high mobility. 
The internet is a communication network that can connect one media to another very easily and quickly. The internet is a new means or support for the communication process that turns into new media or new media to become an intermediary for sending messages carried out by the community because it is quite easy and effective. With "google" capital, people can easily get various information. This change in the ease of obtaining information has made people switch to the internet and gradually will have a sense of dependence on the internet, this is evidenced by the increasing number of internet usage in the community.

Even in the business world, it must be able to balance its effectiveness with this digital era. Such as transportation services, services, and basic needs. One company that serves all the needs in this digital era is GoJek. GoJek is one of the largest technology platforms serving millions of users in Southeast Asia. Starting from transportation services, GoJek also has services that are solutions for daily needs. Starting from the features of GoRide, GoCar, GoSend, GoBox, GoFood, GoMed, GoPay, GoBills, GoPoint, Paylater, GoPulsa, and others. One of the most used features is GoFood. GoFood is a food delivery service feature designed to help people who want to buy food at restaurants or at places to eat without having to leave the house. By ordering on the GoJek application then entering the Gofood feature and you can immediately order the desired food and by entering the full address, the GoJek driver will deliver the food that has been ordered.

In late December 2019, a patient with viral pneumonia due to an unknown microbial agent was reported in Wuhan, China. As of 26 January 2020, more than 2000 cases of $\mathrm{nCoV}-19$ infection have been confirmed. Most of these involved people living in or visiting the city of Wuhan and human-to-human transmission was confirmed. According to data from
Coronavirus COVID-19 Global Cases by the CSSE at Johns Hopkins University reported the latest data with a total of 82,057 cases of corona virus in several regions in China on Sunday, March 29, 2020. However, this corona virus case did not only infect China but also infected China. several countries outside China to a total of 200 countries that were confirmed corona virus. Among them with the highest number of confirmed cases are the United States, Italy, Spain, Germany, France, Iran, England, Switzerland, the Netherlands.

In Indonesia, it was confirmed that this virus existed in February 2020. On Monday, March 2, 2020 President Joko Widodo announced the first case of the corona virus in Indonesia. Since that first case, positive cases confirmed by the corona virus have continued to increase every day. Then the government set 14 days off for schools related to the spread of COVID-19. The government also recommends that employees work at home or Work From Home to anticipate the spread of the COVID-19 virus. The determination of the 14 day holiday period is not without reason. According to the World Health Organization (WHO) the incubation period for the corona virus ranges from 2-14 days after exposure. The incubation period is the time between the onset of infection and the onset of symptoms. Responding to the increasingly widespread COVID-19 outbreak, Twitter social media users reminded each other to be careful and reduce activities outside the home by creating a hashtag \#dirumahaja which is trending on Twitter. Social media users hope that with this trending, the spread of the corona virus will be interrupted. The government also implements Social Distancing or maintains a distance from other people to prevent contracting COVID-19. At this time, outside activities were not possible. However, primary needs such as buying food must always be fulfilled. An alternative way to buy food without having to leave the house is by delivery food or food 
delivery. One company that provides food delivery services is Go-Food.

Therefore, the author wants to examine more deeply how effective the Go-Food food delivery service is in the middle of the corona virus outbreak situation by making a Scientific Writing with the title "The Effectiveness of Go-Food Features in the Gojek Application on the Ease of People Ordering Food When the \#Dirumahaja Program is Implemented.

Based on the background description above, the researchers found the following problem formulations: How effective is the Go-Food feature in the Gojek application on the ease with which people order food when the \#dirumahaja program is implemented?

Limitation of the problem is used to limit its scope so that the research is more focused, focused, and deviates from the main target of the research, so researchers try to limit the problem by conducting research on AKMRTV Jakarta Students, in MarchMay 2020.

The purpose of this study was to determine how much the effectiveness of using the Go-Food feature in the Gojek application on the ease with which people order food when the \#dirumahaja program is implemented for AKMRTV Jakarta students.

\section{B. Konceptual Foundation}

The word communication according to Onong Uchjana Effendi (1992: 3), which comes from the Latin word: communicatio which means "notification" or "exchange of thoughts". Thus, in general, in a communication process there must be elements of the same meaning in order to have an exchange of thoughts or understanding, between the communicator (message spreader) and the communicant (message receiver).
Meanwhile, the communication process can be interpreted as "transfer of information" or messages (massages) from the sender of the message as the communicator and to the recipient of the message as the communicant. The purpose of the communication process is to achieve mutual understanding between the two parties. Before the messages are sent to the communicant, the communicator gives the meanings in the message (decode) which is then captured by the communicant and given the meaning according to the concept he has (encode).

Communication is not only concerned with the issue of exchanging news and messages, but also covers individual and group activities related to exchanging data, facts, and ideas. When viewed from this meaning, there are several functions inherent in the communication process (Onong Uchyana Effendy, 1996), namely as follows.

a. Information, collection, storage, processing, dissemination of news, data, pictures, facts, messages, opinions and comments needed to be understood and act clearly on environmental conditions and other people so as to make the right decisions.

b. Socialization (correctional), providing a source of knowledge that enables people to behave and act as effective members of society so that they are aware of their social functions and can be active in society.

c. Motivation, explaining the short-term or long-term goals of each society, encourages people to make choices about their desires, encourages individual and group activities based on common goals to be pursued.

Communication media are all means used to produce, reproduce, process, distribute or disseminate and convey information. Communication media plays a very important role in people's lives. In simple terms, the communication media is an intermediary in delivering information from the communicator to the communicant which aims to efficiently disseminate the information or message. 
Conventional media is the process of producing and storing data or information which is divided into two parts, namely print media (newspapers, newspapers or magazines) and electronic media (television and radio). The use of print media and electronic media is very much used by the mass media, seen from the amount of information production used by the media, while the ones that are often used are newspapers, magazines, radio, and television. If you look at the old media, it is a form of conventional journalism or by means of journalism using print or electronic media, which is still guided by the $5 \mathrm{~W}+1 \mathrm{H}$.

New media is a medium that offers digitization, convergence, interactivity, and network development related to message creation and message delivery. Its ability to offer interactivity allows users of new media to have the choice of what information to consume, as well as control the output of information generated and make the desired choices. This ability to offer interactivity is a central concept in understanding new media. (Flew, 2005: 11-22)

Quoting from Wikipedia, social media is defined as an online media where users can easily participate, share and create content from blogs, social networks, wikis, forums and virtual worlds. Blogs, social networks, and wikis are the most common types of media used by people around the world. According to Ardianto in the book Communication 2.0 explains that online social media is called online social media, not online mass media because social media has a very strong influence on public opinion that develops in society.

The Go-Jek application is a transportation service application that connects users who want to use ojek transportation with drivers who have registered with Go-Jek. This application can also calculate the price that the user must pay based on the distance (kilometers) between the point of origin and the destination entered in the application. Besides providing transportation services, Go-Jek also has other service features such as: Go-Food (food delivery service), Go-Send (goods delivery service), Go-Shop (online shopping service), and Go-Med ( health services).

Go-Jek does not only serve transportation services, Go-Jek has a feature in the form of a delivery order, namely Go-Food. Go-Food is a food delivery service feature like a delivery order at a restaurant / restaurant. Users can use a smartphone and open the Go-Jek application then enter the Go-Food feature, users can immediately order food from restaurants that have collaborated with Go-Jek, then orders will be immediately delivered according to the user's address without having to leave the house.

Ordering is a purchase process made by a consumer to a seller before the consumer gets the goods. The simplest step of ordering or ordering is to make direct contact with the seller and then the consumer tells the order he wants. After the item you want is confirmed by the seller, then the consumer pays for the item. The ordering process that is often used today is online ordering.

\section{Theoretical Basis}

Technology Acceptance Model

In using the information system, users will consider the benefits and uses of the system. The Technological Acceptance Model (TAM) theory was proposed by Davis (1989) and further developed by several researchers such as Adam et. al. (1992), Szajna (1994), Igbaria et. al. (1995), Venkatesh \& Morris (2000) and Sanjaya (2005). According to Wibowo (2008), the TAM Model is actually adopted from the TRA model, which is a reasoned action with the premise that a person's reaction and perception of 
something will determine the person's attitude and behavior.

This research is supported by the concept of the technology acceptance model (TAM), to make it easier to find out the effectiveness of using the GoFood feature in the Gojek application on the ease with which people order food when the \#dirumahaja program is implemented.

There are two factors that predominantly influence technology integration. The first factor is the user's perception of technology utilization. Meanwhile, the second factor is the ease of use of technology. These two factors influence the willingness to take advantage of technology. Furthermore, the willingness to influence the actual use of technology. User perceptions of ease of use of technology can be influenced by several factors. The first factor lies in the technology itself, for example the user experience of using similar technologies. The second factor is the reputation of the technology that users get. The third factor that affects users' perceptions of youth using technology is the availability of reliable support mechanisms. A trusted support mechanism will affect user confidence in the ease of technology, users will feel confident that there is a mechanism.

\section{METHODS AND MATERIAL}

Researchers use this type of quantitative method. Quantitative research is research that describes or explains a problem whose results can be generalized. This study uses survey method research using a questionnaire or questionnaire as a tool to obtain more detailed and reliable data. The survey method is a research method using a questionnaire as an instrument for data collection. The subjects in this study were AKMRTV Jakarta students who used the Go-Jek application, the Go-Food feature. The object of this research is the effectiveness of using the Go-
Food feature in the Gojek application for the convenience of people ordering food when the \#dirumahaja program is implemented. Based on the research object, the population in this study were students of the AKMRTV Jakarta faculty of communication science class 2017, 2018, and 2019. The sampling technique used in this study was Probability Sampling.

\section{A. Validity Test Results}

Validity testing is carried out to determine whether the measuring instrument (instrument) used meets the requirements of a good measuring instrument so that it can produce data that is in accordance with what is measured, testing data through data validity and reliability testing. The test was carried out using 244 respondents consisting of 105 students of class 2017, 73 students of class 2018, and 66 students of class 2019. A statement item can be said to be valid if $r$ count $>r$ table or can be symbolized by $p>0.3610$, but if $\mathrm{p}<0.3610$ means the statement item is said to be invalid.

\section{B. Reliability Test Results}

Reliability test is used to measure the level of consistency of respondents' responses to statement items in accordance with the respondent's understanding of the statements in the proposed questionnaire. The reliability test was carried out using the Cronbach Alpha method, the results obtained from the calculation of the reliability coefficient for the variable were said to be reliable if the alpha value was greater than the $r$ table or close to zero.

The conclusion from the validity test which states that all instruments are valid statements and the reliability test states that the instruments are reliable, then the questionnaire is appropriate to be distributed to research respondents. The data generated from 
distributing questionnaires can be used for further analysis.

\section{Simple Linear Regression Test}

Simple linear regression test is used to analyze the relationship between the independent variable and the dependent variable. From the table above, it is known that the correlation or relationship value $(R)$ is 0.591. For $\mathrm{R}$ square or so-called coefficient of determination, which is obtained from the squaring of $\mathrm{R}$, it is known that the coefficient of determination is 0.349 or $34.9 \%$. This figure means that $22.6 \%$ of the Go-Food features in the Gojek application are effective in making it easier for people to order food when the \#dirumahaja program is implemented, while $65.1 \%$ is influenced by other factors. The constant value or the one symbolized by (a) is 13.172. Meanwhile, the value of the variable X (b) in column $\mathrm{B}$ is 0.382 .

\section{RESULTS AND DISCUSSION}

In the results of the validity test of variable $\mathrm{X}$, namely the effectiveness of the Go-Food feature on the Gojek application and variable $\mathrm{Y}$, namely the ease with which people order food when the \#dirumahaja program is implemented, it is stated that all statements are said to be valid, because $R$ count is greater than $\mathrm{R}$ table. This means that all statements can be said to be feasible so that further analysis can be carried out.

In the reliability test results, the Cronbach Alpha value in variable $\mathrm{X}$ is 0.950 while in variable $\mathrm{Y}$ is 0.909 . And after the trust test is carried out, it can be said that scientific writing entitled the effectiveness of the Go-Food feature in the Gojek application on the ease with which people order food when the \#dirumahaja program is implemented is the result of reliable scientific writing, because it is included in the category of high and perfect confidence testing. Then this research can be used to conduct research at a later stage.

Based on the value of the determination coefficient which is $34.9 \%$, it means that $34.9 \%$ of the Go-Food features in the Gojek application are effective in the ease of ordering food for people. While the other $65.1 \%$ are influenced by other factors.

\section{IV.CONCLUSION}

From the results of research in the field that has been carried out, and based on statistical tests that have been calculated using IBM SPSS version 25.0, with the title of scientific writing on the Effectiveness of the Go-Food Feature in the Gojek Application on the Ease of Public Ordering Food When the \#dirumahaja Program is Implemented among AKMRTV students Jakarta, it can be concluded that there is a strong effectiveness of the Go-Food Feature on the ease of ordering food. This is also supported by the Technological Acceptance Model (TAM) theory which can affect the use of technology. TAM has two factors that influence technology integration, namely user perceptions of technology utilization and ease of use of technology. Then in the user's perception of the use of technology supported by other factors, namely experience, reputation, and reliable support mechanisms will encourage user perceptions to be more positive.

\section{v. CONCLUSION}

From the results of research in the field that has been carried out, and based on statistical tests that have been calculated using IBM SPSS version 25.0, with the title of scientific writing on the Effectiveness of the Go-Food Feature in the Gojek Application on the Ease of Public Ordering Food When the \#dirumahaja Program is Implemented among AKMRTV students 
Jakarta, it can be concluded that there is a strong effectiveness of the Go-Food Feature on the ease of ordering food. This is also supported by the Technological Acceptance Model (TAM) theory which can affect the use of technology. TAM has two factors that influence technology integration, namely user perceptions of technology utilization and ease of use of technology. Then in the user's perception of the use of technology supported by other factors, namely experience, reputation, and reliable support mechanisms will encourage user perceptions to be more positive.

\section{REFERENCES}

Book

[1]. Ardianto, Elvinaro, dkk. 2007. Komunikasi Massa, Suatu Pengantar. Edisi Revisi. Bandung: Simbiosa Rekatama Media.

[2]. Bungin, Burhan. 2014. Metode Penelitian Sosial: Format-Format Kuantitatif \& Kualitatif. Airlangga University Press.

[3]. Cangara, Hafied. 2016. Pengantar Ilmu Komunikasi, Edisi Kedua. Jakarta. Raja Grafindo Persada.

[4]. Effendy, Onong Uchjana. 1992. Hubungan Masyarakat, Suatu Studi Komunikasi. Bandung: PT Remaja Rosdakarya.

[5]. Effendy, Onong Uchjana. 1966. Propaganda Melalui Siaran Radio. Bandung: Tesis Fakultas Publistik Universitas Pajajaran.

[6]. Flew, T. 2005. New Media: an Introduction. Second Edition. UK: Oxford University.

[7]. Kriyantono, Rachmat. 2016. Teknik Praktis Riset Komunikasi: Disertai Contoh Praktis Riset Media, Public Relations Advertising, Komunikasi, Organisasi, Komunikasi Pemasaran, Edisi Pertama. Jakarta : Kencana Prenada Media Group.
[8]. Ruslan, Rosady. 2014. Manajemen Public Relations \& Media Komunikasi: Konsepsi dan Aplikasi. Depok : PT Rajagrafindo Persada.

[9]. Sugiyono. 2002. Statistika untuk Penelitian. Alfabeta. Bandung.

[10]. Sugiyono. 2011. Metode penelitian Kuantitatif, Kualitatif, dan R\&D. Bandung: CV AFABETA.

[11]. Sugiyono. 2013. Metode Penelitian Kuantitatif, Kualitatif dan R\&D. Bandung: Alfabeta.

[12]. Suharsimi, Arikunto. 2009. Manajemen Penelitian. Jakarta: Rineka Cipta.

[13]. Sunyoto, Danang. 2013. Teori, Kuesioner, \& Analisis Data : Untuk Pemasaran dan Perilaku Konsumen. Yogyakarta: Graha Ilmu.

[14]. Suryanto. 2015. Pengantar Ilmu Komunikasi. Jakarta : CV Pustaka Setia.

[15]. Wibowo, A. 2008. Kajian Tentang Perilaku Pengguna Sistem Informasi Dengan Pendekatan Technology Acceptance Model (TAM). ResearchGate , 1-9.

[16]. Widjaja, A.W. 1993. Komunikasi, Komunikasi dan Hubungan Masyarakat. Jakarta: Bumi Aksara.

Journal

[17]. Hidayatullah, Syarif, et all. 2018. Perilaku Generasi Milenial dalam Menggunakan Aplikasi Go-Food. UNMER Malang.

[18]. Kurnia, Novi. 2005. Perkembangan Teknologi Komunikasi dan Media Baru: Implikasi terhadap Teori Komunikasi. Vol. 6, Desember, MediaTor. 291 - 296.

[19]. Nurbayti. 2019. Tren Pengguna Aplikasi GoFood di Era Digital. Vol.1, Universitas Amikom Yogyakarta. 1-31.

[20]. Watie, Errika Dwi Setya. 2011. Komunikasi dan Media Sosial. Vol. 3, Juli, THE MESSENGER. 69 -75 .

Skripsi:

[21]. Lutviah, Evi. 2019. Analisis Faktor yang Mempengaruhi Keputusan Menggunakan Aplikasi Go-Jek Fitur Go-Food. UIN Jakarta. 
[22]. Setyaningsih, Rachmawati. 2018. Analisis Faktor-Faktor yang Mempengaruhi Pemanfaatan Go-Food. UII Yogyakarta.

Internet:

[23]. Christiastuti, Novi., "Sebagian Besar Kasus Corona Kini di Luar China, Tersebar di 140 Negara Lain", https://news.detik.com/internasional/d-

4941173/sebagian-besar-kasus-corona-kini-diluar-china-tersebar-di-140-negara-lain

[24]. Della, Dorea., "Media Lama dan Media Baru", https://www.academia.edu/16858182/Media_La ma_dan_Media_Baru

[25]. Fatin, Nur., "Pengertian Studi Literatur", http://seputarpengertian.blogspot.com/2017/09/ pengertian-studi-literatur.html

[26]. Hopkins, Johns., "Coronavirus COVID-19 Global Cases", https://101kfe.id/coronaviruscovid-19-global-cases-by-johns-hopkins-cssemobile-version/

[27]. Kompas.com., "Update Virus Corona di Dunia 29 Maret: 662.073 Kasus di 200 Negara, 139.426 Sembuh", https://www.kompas.com/tren/read/2020/03/29 /092500765/update-virus-corona-di-dunia-29maret--662.073-kasus-di-200-negara-139.426

[28]. Nuraini, Tantiya Nimas., "Cerita Lengkap Asal Mula Munculnya Virus Corona di Indonesia", https://www.merdeka.com/trending/ceritalengkap-asal-mula-munculnya-virus-corona-diindonesia.html

[29]. Semangat Baru Gojek https://www.gojek.com/about https://www.gojek.com/gofood/

[30]. Utama, Felldy., "Mengapa Harus Libur 14 Hari untuk Cegah Korona? Ini Penjelasan IDI", https://www.inews.id/news/nasional/mengapaharus-libur-14-hari-untuk-cegah-korona-inipenjelasan-idi
[31]. WeAreSocial., "Global Digital Report", https://wearesocial.com/global-digital-report2019

[32]. Wikipedia, "Media Sosial", https://id.wikipedia.org/wiki/Media_sosial\#: :te $\mathrm{xt}=$ Media\%20sosial\%20(sering\%20disalahtulisk an\%20sebagai,wiki\%2C\%20forum\%20dan\%20 dunia\%20virtual.

\section{Cite this article as :}

Edy Prihantoro, Didin Mukodim, Noviawan Rasyid Ohorella, Astiyani Lestari, "Go-Food Features and Social Implications in The Community When \#Dirumahaja Programs Are Implemented", International Journal of Scientific Research in Science and Technology (IJSRST), Online ISSN : 2395-602X, Print ISSN : 2395-6011, Volume 7 Issue 6, pp. 255-262, November-December 2020. Available at doi : https://doi.org/10.32628/IJSRST207621 Journal URL : http://ijsrst.com/IJSRST207621 